\title{
A Study on the Effect of Progesterone on Coronary and Femoral Blood Flow in Prepubertal Female Anesthetized Dogs
}

\author{
Mahmoud A. El-Gharieb and Romysaa A. El-Sherbeny \\ Department Of Physiology, Tanta University
}

\begin{abstract}
This work was undertaken to study the effects of progesterone on the coronary and femoral blood flow. In 18 prepubertal female dogs anesthetized with thiopental sodium, changes in the coronary and femoral flow caused by intravenous infusion of progesterone were assessed by collecting blood through Mrowtiz cannula form coronary sinus and femoral blood through a catheter inserted inside the femoral vein after ligation of the external iliac artery. In 6 dogs, infusion of $1 \mathrm{mg} / \mathrm{kg}$ of progesterone increased the coronary and femoral blood flow. The vasodilator effects of the hormone were enhanced by graded increases in the dose between 1, 2 and 3 $\mathrm{mg} / \mathrm{kg}$. The mechanisms of these responses were studied in the dogs by repeating the experiment after the arterial blood pressure and heart rate had returned to the control values before infusion. After administration of $\alpha$ blocker (phentolamine) or $\beta$ blocker ( propranolol), they did not affect the responses elicited by progesterone in the femoral blood flow. Also, injection $\alpha, \beta$ sympathetic blocker and cholinergic blocker (atropine) did not abolish the effect of progesterone on the coronary flow. Injection of $N$-nitro-L-arginine methyl ester (L-NAM) alone or with progesterone into the coronary or the femoral artery caused prevention in the increase in the coronary and femoral flow. The present study showed that, intravenous infusion of progesterone dilated the coronary and the femoral arteries. The mechanism of this response did not involve stimulation of sympathetic or parasympathetic vasodilator receptors, but may be through the local action.
\end{abstract}

\section{INTRODUCTION}

It is widely accepted that estrogen play a beneficial role in the coronary circulation and can modify the cardiovascular disease risk, but the role of progesterone has been less clear. For instance, it has been shown that, the acute administration of ethinyl oestradiol and $17 \beta$ - oestradiol increased the coronary blood flow in women $^{[1]}$ and in anaesthetized pigs ${ }^{[2]}$. These results were consistent with reports involving that $17 \beta$ - oestradiol relaxed isolated human coronary ${ }^{[3]}$, pre-contracted pig coronary artery rings and strips with ${ }^{[4]}$ and without functioning endothelium ${ }^{[5]}$. In contrast, there has been little information on the acute effect of progesterone on coronary blood flow. For instance, progesterone was found to induce coronary vasoconstriction in the isolated rabbit heart ${ }^{[6]}$, but relax pre contracted rabbit coronary artery preparation $^{[7]}$. Progesterone has been 
also found to relax pre-contracted pig coronary artery strip ${ }^{[8]}$ and pig coronary smooth muscles ${ }^{[9]}$. Also progesterone was found to relax precontracted coronary micro-vessels of $\operatorname{dogs}^{[10]}$.

There is little and conflicting information regarding the acute effects of progesterone on coronary and peripheral blood flow and their mechanisms. For instance, the intravenous infusion of progesterone in anesthetized pigs caused coronary vasodilatation which involved the release of endothelial vascular factors $^{[8]}$. Others have shown that vaginal implants of progesterone in non-pregnant ovariectomized sheep increased nitric oxide synthase expression in the endothelium of the uterine artery but not in that of the omental, renal or mammary $\operatorname{arteries}^{[11]}$, and that progesterone relaxes pre-contracted segments of small saphenous artery of the rat ${ }^{[\mathbf{1 2 ]}}$. Also, it has been reported in humans that acute intra-arterial progesterone did not significantly affect forearm blood flow, particularly that mediated by endothelial mechanisms ${ }^{[13,14]}$, and that progesterone applied as a vaginal cream decreased forearm blood flow $^{[15]}$.

The issue of whether or not the effect of progesterone on blood flow differs between vascular regions assumes a particular relevance. There are indications in humans to add progesterone to estrogen therapy, which does not appear to modify substantially the effects of estrogen alone ${ }^{[16,17]}$. It is unknown whether regional differences exist as regarding the effect of progesterone on blood flow, which might explain absence of additive effects.

The present investigation was therefore designed to determine the effect of administration of progesterone on coronary and femoral blood flow in anesthetized female dogs and to determine the mechanisms involved. For this purpose, experiments were performed during constant heart rate and arterial blood pressure to avoid interference by hemodynamic and reflex effects.

\section{MATERIALS \& METHODS}

The experiments were carried out in 18 pre-pubertal female dogs in order to exclude the effect of endogenous progesterone on their blood flow, weighing $10-15 \mathrm{~kg}$,. The experiments were begun after at least 30 min of steady state conditions with respect to measured hemodynamic variables (heart rate and arterial blood pressure). The dogs were divided into three groups.

Group (1): Consisted of 6 dogs which were administrated by $1 \mathrm{mg} / \mathrm{kg}$ of progesterone (Sigma) dissolved in saline. The experiment was repeated by progesterone injection at increased doses of $2 \mathrm{mg} / \mathrm{kg}$ and $3 \mathrm{mg} / \mathrm{kg}^{[18,19]}$.

Group (2): Consisted of 6 dogs which were injected by atropine(Sigma) in a dose of $(0.5 \mathrm{mg} / \mathrm{kg})$, propranolol (Sigma) in a dose of $(0.5 \mathrm{mg} / \mathrm{kgm}$ body weight) and phentolamine (Ciba Geigy) in a dose of $(1 \mathrm{mg} / \mathrm{kg})$ in the coronary artery followed by progesterone infusion in a dose of $1 \mathrm{mg} / \mathrm{kg}$. After the resting heart rate and arterial blood pressure were established, the dogs were injected by L-NAM (N-nitro- $L$-arginine methyl 
ester (Sigma) in a dose of $10 \mathrm{mg} / \mathrm{kg}^{[2]}$, which was performed by using a catheter connected to a butterfly needle inserted into the arteries.

Group (3): Consisted of 6 dogs which were administrated by propranolol in a dose of $(0.5 \mathrm{mg} / \mathrm{kg}$ body weight $)$ followed by progesterone injection in the femoral artery in a dose of $1 \mathrm{mg} / \mathrm{kg}$. After the resting heart rate and arterial blood pressure were established, phentolamine in a dose of $(1 \mathrm{mg} / \mathrm{kg}$ ) followed by progesterone injection in a dose of $1 \mathrm{mg} / \mathrm{kg}$. After established resting conditions, dogs which were injected by L-NAM ( Nnitro- $L$-arginine methyl ester in a dose of $2 \mathrm{mg}$ for $1 \mathrm{~m} / \mathrm{min}^{[2]}$, which was performed by using a catheter inside the femoral artery.

\section{Experimental Protocol:}

The animals, which were fasted overnight, were anesthetized by intravenous thiopental sodium 15 $\mathrm{mg} / \mathrm{kg}$,(Biochemie $\mathrm{GmbH}$, ViennaAustria), and artificially ventilated with oxygen-enriched air using a respiratory pump (Harvard Apparatus, USA). Anesthesia was maintained throughout the experiments by continuous i.v. infusion of thiopental sodium $(7 \mathrm{mg} / \mathrm{kg} / \mathrm{h})^{[17]}$.

The chest was opened at the left forth intercostals space, the pericardium was cut and direct coronary blood flow was measured by means of Morawitz cannula.The abdomen was opened with a mid-line incision, the femoral blood flow of the dog was obtained from the lower limb by legation of the iliac vessels, and the blood flow $\mathrm{ml} /$ minute through the hind limb was measured by collecting the blood passing out from the femoral vein ${ }^{[9]}$. The blood flow was measured by a catheter that was drain into calibrated vessel in vitro at the end of each experiment the blood was returned back through the maintained infusion. Coagulation of the blood was avoided by the intravenous injection of heparin (Parke-Davis; initial doses of 500 $\mathrm{IU} / \mathrm{kg}$, and subsequent doses of 50 $\mathrm{IU} / \mathrm{kg}$ every $\left.30 \mathrm{~min}^{[8]}\right)$. At the end of the experiment, each animal was killed by an intravenous injection of $90 \mathrm{mg} / \mathrm{kg}$ sodium pentobarbitone.

Recordings taken for $10 \mathrm{~min}$ during the steady state before infusion of progesterone were used as control, then the blood was returned back to the dog. The effects of graded administration of the hormone were examined by infusing 1,2 and 3 $\mathrm{mg} / \mathrm{kg}$ of progesterone. Subsequent infusions were carried out at least 20 min after blood flows had returned to the control levels observed before starting the previous one. Each infusion was completed in 1 hour and changes in measured blood flows caused by each dose of progesterone were compared with control values obtained before starting the infusion.

\section{Statistical analysis}

Data from the present work were expressed as means $\pm \mathrm{SD}$. The results were analyzed using ANOVA and post analysis tests were carried out using t-test which used to examine changes in measured hemodynamic variables caused by infusion of progesterone, $\mathrm{P}<0.05$ was considered statistically significant, also correlation between different doses of progesterone were studied. 


\section{RESULTS}

\section{The results of the present work} showed the following effects:

1. The effects of graded doses of progesterone on coronary and femoral blood flow of premature female dogs showed a significant increase of both coronary and femoral blood flow $\mathrm{ml} / \mathrm{min}$ after injection of $1 \mathrm{mg}$ of progesterone in relation to the resting coronary and femoral blood flow $\mathrm{ml} / \mathrm{min}$ $(\mathrm{P}<0.05)$. The injection of $2 \mathrm{mg}$ and $3 \mathrm{mg}$ of progesterone after resting conditions were established showed also significant increase in the coronary and femoral blood flow $\mathrm{ml} / \mathrm{min}(\mathrm{P}<0.05)$ Table (1) and Fig. $(1 \& 2)$. Also there was a positive correlation between the injected doses of 1,2and $3 \mathrm{mg}$ progesterone The results showed no significant changes of arterial blood pressure $\mathrm{mmHg}$ and heart rate/min at resting conditions or at different doses of progesterone $(\mathrm{p}<0.05)$.

2. The effects of cholinergic blocker (atropine), $\alpha \quad \beta \quad$ sympathetic blockers (phentolamie and propranolol) and L-NAM followed by progesterone on coronary blood flow $\mathrm{ml} / \mathrm{min}$ of premature female dogs showed that the injection of atropine, $\alpha$ and $\beta$ sympathetic blockers followed by progesterone increase the coronary blood flow $\mathrm{ml} / \mathrm{min}$ significantly $(\mathrm{P}<0.05)$. The injection of L-NAM alone or followed by progesterone resulted in significant reduction of coronary blood flow $\mathrm{ml} / \mathrm{min}(\mathrm{P}<0.05)$, Table (2)and Fig(3).

3. The effects of $\alpha, \beta$ sympathetic blockers (phentolamie and propranolol) and L-NAM followed by progesterone on femoral blood flow premature female dogs showed that the injection of phentolamine or propranolol followed by progesterone resulted in a significant increase of femoral blood flow $\mathrm{ml} / \mathrm{min}(\mathrm{P}<0.05)$. Moreover the injection of L-NAM alone or followed by followed by progesterone resulted in significant reduction of femoral blood flow $\mathrm{ml} / \min (\mathrm{P}<0.05), \quad$ Table(3) and Fig(4). 
Table (1): Effects of graded doses of progesterone on coronary and femoral blood flow ( $\mathrm{ml} / \mathrm{min})$ of premature female dogs:

\begin{tabular}{|c|c|c|c|c|c|c|}
\hline Parameter & $\begin{array}{c}\text { Control } \\
\text { BF } \\
\text { Before }\end{array}$ & $\begin{array}{l}\text { Progesterone } \\
1 \mathrm{mg}\end{array}$ & $\begin{array}{c}\text { Control } \\
\text { BF } \\
\text { Before }\end{array}$ & $\begin{array}{l}\text { Progesterone } \\
2 \mathrm{mg}\end{array}$ & $\begin{array}{c}\text { Control } \\
\text { BF } \\
\text { Before }\end{array}$ & $\begin{array}{c}\text { Progesterone } \\
\text { 3mg }\end{array}$ \\
\hline $\begin{array}{c}\text { Coronary } \\
\text { BF ml/min } \\
\text { (mean } \\
\text { 6+SD) }\end{array}$ & $42.6 \pm 1.65$ & $51.7 \pm 1.14 *$ & $42.7 \pm 1.67$ & $52.4 \pm 1.15^{*}$ & $42.9 \pm 1.50$ & $53.1 \pm 0.98 *$ \\
\hline$t$ & & 9* & & $9.7^{*}$ & & $10^{*}$ \\
\hline $\mathbf{P}$ & & $<0.05$ & & $<0.05$ & & $<0.05$ \\
\hline $\begin{array}{c}\text { Femoral BF } \\
\text { ml/min } \\
(\text { mean } \\
6+\text { SD) }\end{array}$ & $32.7 \pm 1.04$ & $42.5 \pm 1.63 *$ & $32.8 \pm 1.08$ & $44.3 \pm 1.43 *$ & $32.9 \pm 0.96$ & $45.2 \pm 1.24 *$ \\
\hline$t$ & & $9.9^{*}$ & & $11.5^{*}$ & & $12.3^{*}$ \\
\hline $\mathbf{P}$ & & $<0.05$ & & $<0.05$ & & $<0.05$ \\
\hline $\begin{array}{l}\text { ABP mmHg } \\
\text { (mean } \\
6 \pm \text { SD) }\end{array}$ & $113.3 \pm 6.12$ & $113 \pm 6.6$ & $113.3 \pm 6.47$ & $113.8 \pm 6.49$ & $113.5 \pm 6.62$ & $113.5 \pm 6.12$ \\
\hline $\mathbf{t}$ & & 1 & & 1.5 & & 1 \\
\hline $\mathbf{P}$ & & $>0.05$ & & $>0.05$ & & $>0.05$ \\
\hline $\begin{array}{l}\text { Heart rate } \\
\text { /min (mean } \\
6 \pm \text { SD) }\end{array}$ & $119.3+5.78$ & $121.1+5.98$ & $119.8 \pm 5.87$ & $121.6+5.46$ & $119.5+5.24$ & $119.6 \pm 4.67$ \\
\hline$t$ & & 1.83 & & 1.83 & & 1.5 \\
\hline $\mathbf{P}$ & & $>0.05$ & & $>0.05$ & & $>0.05$ \\
\hline
\end{tabular}

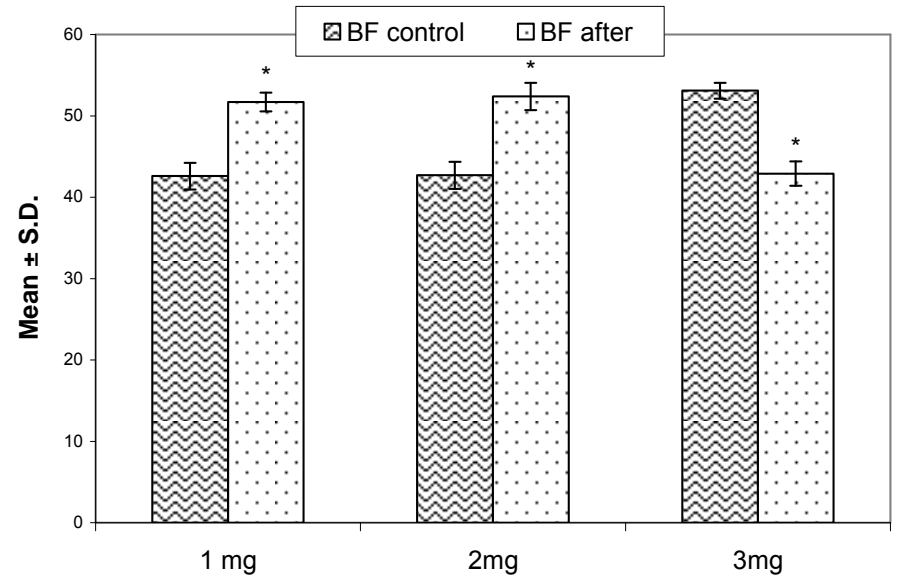

Fig. (1): Effects of graded doses of $1 \mathrm{mg}, 2 \mathrm{mg}$ and $3 \mathrm{mg} / \mathrm{kg}$ progesterone on coronary blood flow $\mathrm{ml} / \mathrm{min}$ of premature female dogs.

N.B: BF after Blood flow after injection of progesterone 


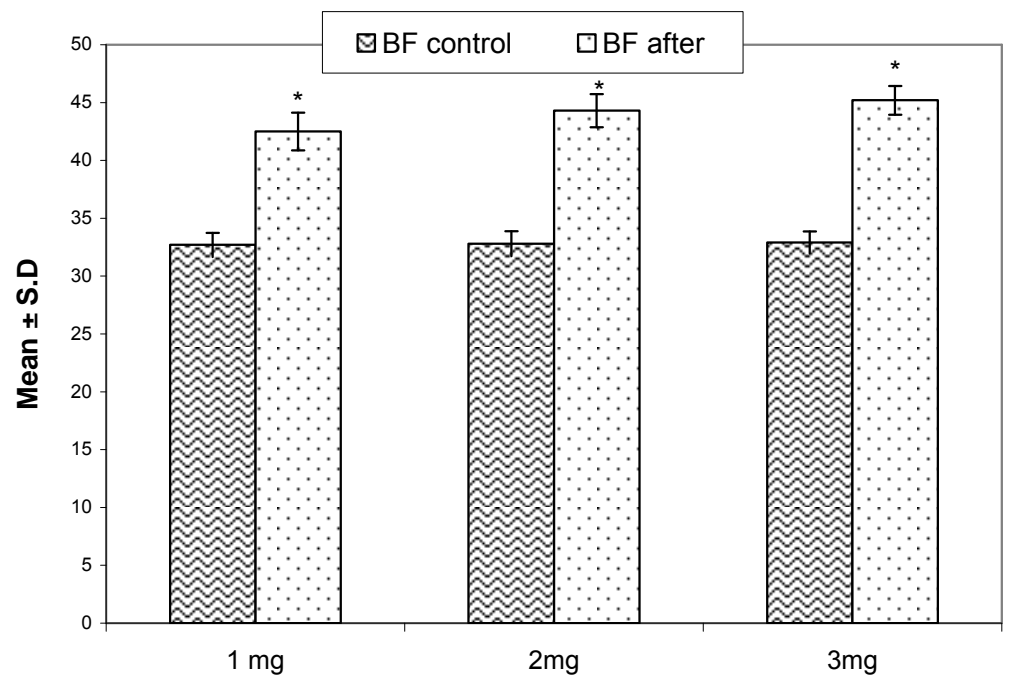

Fig. (2): Effects of graded doses of progesterone on Femoral blood flow $\mathrm{ml} / \mathrm{min}$ of premature female dogs.

Table (2): Effects of atropine, $\alpha, \beta$ blockers and L-NAM alone and followed by progesterone on coronary blood flow $\mathrm{ml} / \mathrm{min}$ of premature female dogs:

\begin{tabular}{|c|c|c|c|c|c|}
\hline Parameter & $\begin{array}{c}\text { Control } \\
\text { BF } \\
\text { Before }\end{array}$ & $\begin{array}{c}\text { Atropine }, \boldsymbol{\alpha}, \boldsymbol{\beta} \text { blockers } \\
\text { followed by } \\
\text { progesterone }\end{array}$ & $\begin{array}{c}\text { Control BF } \\
\text { Before }\end{array}$ & L-NAM & $\begin{array}{c}\text { L-NAM } \\
\text { followed by } \\
\text { progesterone }\end{array}$ \\
\hline $\begin{array}{c}\text { Coronary BF } \\
\mathbf{m l} / \mathbf{m i n}(\mathbf{m e a n} \mathbf{6} \pm \text { SD) }\end{array}$ & $43.2 \pm 1.08$ & $49.3 \pm 1.6^{*}$ & $43.5 \pm 1.11$ & $31.25 \pm 0.32^{*}$ & $31.5 \pm 1.13^{*}$ \\
\hline $\mathbf{t}$ & & $6.1^{*}$ & & $12.2^{*}$ & $11.9^{*}$ \\
\hline $\mathbf{P}$ & & $<0.05$ & & $<0.05$ & $<0.05$ \\
\hline
\end{tabular}




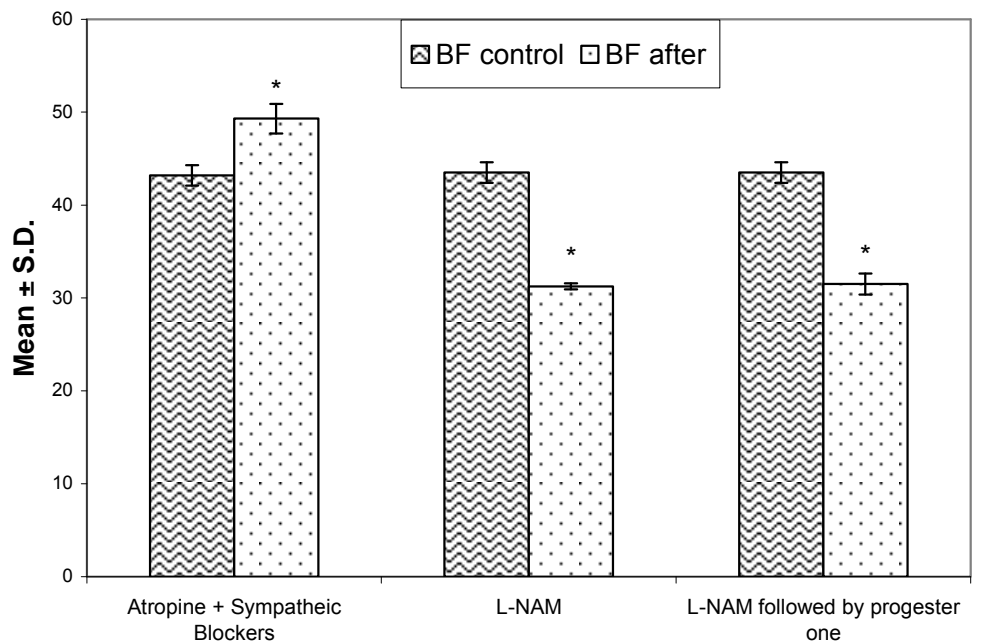

Fig. (3): Effects of atropine $\alpha \beta \quad$ blockers and L-NAM followed by progesterone on coronary flood flow $\mathrm{ml} / \mathrm{min}$ of premature female dogs

Table (3): Effects of $\alpha, \beta$ blocker and L-NAM alone and followed by progesterone on femoral blood flow $\mathrm{ml} / \mathrm{min}$ of premature female dogs:

\begin{tabular}{|c|c|c|c|c|c|c|c|c|}
\hline Parameter & $\begin{array}{c}\text { Control } \\
\text { BF } \\
\text { Before }\end{array}$ & $\begin{array}{c}\alpha \text { blocker } \\
\text { Phentolamine }\end{array}$ & $\begin{array}{c}\text { Control } \\
\text { BF } \\
\text { Before }\end{array}$ & $\begin{array}{c}\beta \text { blockers } \\
\text { propranolol }\end{array}$ & $\begin{array}{c}\text { Control } \\
\text { BF } \\
\text { Before }\end{array}$ & L-NAM & $\begin{array}{c}\text { Control } \\
\text { BF } \\
\text { Before }\end{array}$ & $\begin{array}{c}\text { L-NAM } \\
\text { followed by } \\
\text { progesterone }\end{array}$ \\
\hline $\begin{array}{l}\text { Femoral } \\
\text { BF } \\
\mathrm{ml} / \mathrm{min}(\mathrm{me} \\
\text { an 6+SD) }\end{array}$ & $\begin{array}{l}32.7 \pm \\
0.97\end{array}$ & $\begin{array}{c}41.65 \pm \\
1.06^{*}\end{array}$ & $\begin{array}{c}32.8 \pm \\
0.92\end{array}$ & $\begin{array}{l}42.2 \pm \\
1.04 *\end{array}$ & $\begin{array}{c}33.1 \pm \\
1.03\end{array}$ & $\begin{array}{c}21.28 \pm \\
0.49 *\end{array}$ & $\begin{array}{c}33.1 \pm \\
1.03\end{array}$ & $\begin{array}{l}21.3 \pm \\
0.57^{*}\end{array}$ \\
\hline$t$ & & $8.9 *$ & & $9.4^{*}$ & & $11.6^{*}$ & & $11.6^{*}$ \\
\hline $\mathbf{P}$ & & $<0.05$ & & $<0.05$ & & $<0.05$ & & $<0.05$ \\
\hline
\end{tabular}

$\mathrm{BF}=$ Blood flow

$*=$ denotes statistical significance.

$\mathrm{P}<0.05=$ denotes significant results

$\mathrm{P}>0.05=$ Denotes non significant results. 


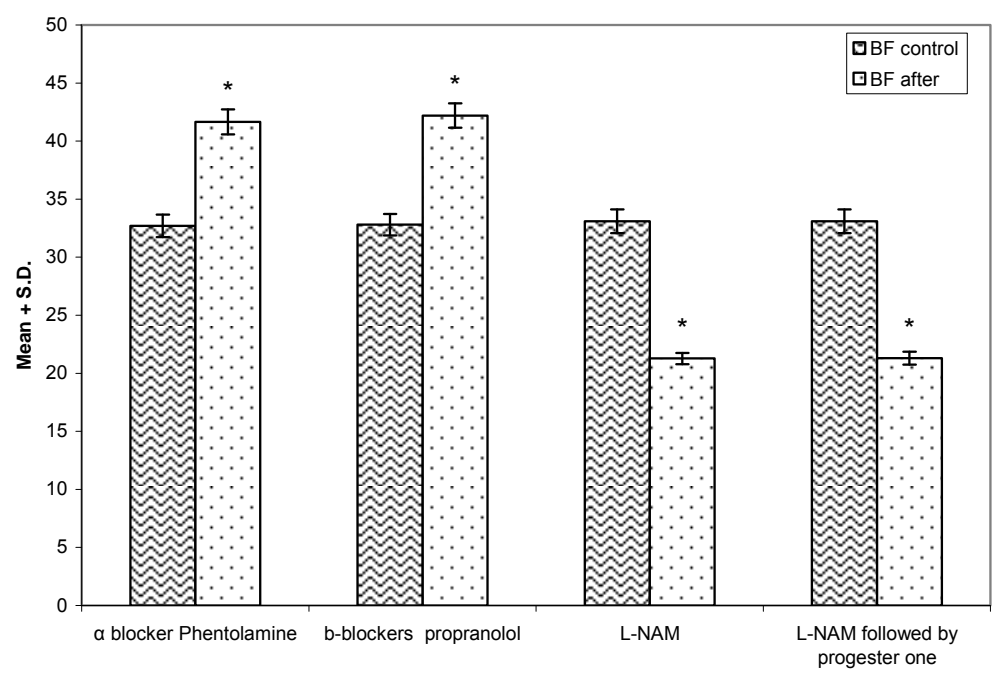

Fig. (4): Effects of a $\beta$ lockers and L-NAM followed by progesterone on femoral blood flow $\mathrm{ml} / \mathrm{min}$ of premature female dogs.

\section{DISCUSSION}

The present investigation was designed in pre-pubertal female dogs to examine the effects of progesterone which occurred within 1 hour and to quantifying regional vascular effects and to determine their mechanisms. The present results showed that intravenous infusion of progesterone resulted in an increase in coronary and femoral blood flow. These findings were obtained in the absence of significant changes in arterial blood pressure and heart rate, indicating that progesterone infusion resulted in a vasodilatation in these vascular beds. The mechanism of the effect of progesterone did not involve sympathetic effects. This work was designed to quantify the observed changes in blood flow which can be attributed primarily to progesterone.

The present results showed significant increase in the coronary blood flow, it is possible to relate the observed changes to the intravenous infusion of progesterone mainly. Also the observed increase in coronary blood flow was obtained in the absence of confounding factors which can affect this flow, such as arterial blood pressure and heart rate ${ }^{[8]}$. The response to progesterone of an increase of the coronary blood flow was not altered following blocking of vagal and sympathetic nerves. Also the ability to augment the increase in the coronary blood flow by increase the dose of progesterone proved the direct relationship between the hormone and the coronary response. In addition, blocking of cholinergic 
and sympathetic flow to the heart before progesterone injection did not affect the increase in the coronary blood flow.

The observed changes in femoral blood flow may be due to arterial distension ${ }^{[12]}$ or stimulation of arterial baroreceptors ${ }^{[20]}$ can affect blood flow to the kidney and lower limbs through sympathetic mechanisms. Also, such effects were unlikely since the responses of increase in blood flow to progesterone were not altered following blockade of sympathetic effects. In addition, the magnitude of the response of increase of blood flow in these regions was augmented by increasing the dose of infused progesterone. Using such an experimental design, it was possible to attribute the regional vasodilatation solely to progesterone. This is important in quantifying progesterone-induced increase in blood flow and in examining the mechanisms involved. During the examination of the mechanisms responsible for the progesteroneinduced vasodilatation. Firstly, the infusion experiments before and following propranolol and phentolamine were performed in the absence of changes in arterial blood pressure and heart rate, thereby excluding the possibility of their direct or secondary reflex interference. Progesterone has been found to modulate arterial baroreceptor control of autonomic neural output ${ }^{[21,22]}$. Secondly, the dose of propranolol has been used in anesthetized pigs to block adrenergic receptors $^{[2]}$ and the dose of phentolamine has been shown to abolish the reflex coronary vasoconstriction caused by distension of the gallbladder ${ }^{[16]}$ and has been previously used to block -adrenergic receptors $^{[2]}$. Similar doses of the blocking agents have been used in anesthetized dogs to achieve autonomic blockade ${ }^{[23]}$. Similarly, the doses of local L-NAME were used to abolish regional vasodilatation induced by intravenous infusion of progesterone $e^{[18]}$. L-NAME was administered locally into the regional circulation proved that progesteroneinduced vasodilatation was not caused by changes in sympathetic effects. Instead, this response was blocked by nitric oxide blocker, L-NAME. Although this technique does not determine the origin of nitric oxide, but it may be involved, since LNAME is known in general to inhibit the formation of nitric oxide ${ }^{[24]}$. Also, it was reported that chronic administration of progesterone to female pubertal pigs caused regional difference of blood flow [25]. However, the findings on the observed distribution of the acute vasodilator effect of estrogen and progesterone would cause a more widespread vasodilatation than each alone. This theory would at least explain the reported difficulty of showing any detrimental vascular effect when adding progesterone to estrogen in humans ${ }^{[18]}$.

\section{CONCLUSION}

The present investigation has shown that the acute administration of progesterone caused a vasodilatation in the coronary and femoral vascular beds by local vascular mechanism. 


\section{REFERENCES}

1. Blumenthal R, Briker J, Resar J, Gloth S, Zacur H, Coombs $V$, Gerstenblith $G$ and Reis S(1997): Long term estrogen thereby abolishes acute estrogen induced coronary flow augmentation in postmenopausal women. American Heart J.133:323-328.

2. Vacca G, Battaglia A, Grossini E, Mary D, Molinari $\mathbf{C}$ and Surico N (1999): The effect of $17-\beta$ oestradiol on regional blood flow in anaesthetized pigs. J. Physiol. 514:875-884.

3. Brarton $M$, Cremer $J$ and Mugge A(1998): 17- $\beta$ oestradiol acutely (correction of activity) improves endothelium- dependent relaxation to bradykinin in isolated human coronary arteries. European J Pharmacol.362: 7376.

4. Teoh $H$ and Man R(1999): Progesterone modulates oestradiol actions: acute effects at physiological concentrations. European J Pharmacol. 378:5762.

5. Crews $J$ and Khalil $R(1999)$ : Antagonistic effects of $17-\beta$ oestradiol, progesterone and testosterone on $\mathrm{Ca}^{+2}$ entry mechanisms of coronary vasoconstriction. Atherosclerosis, Thrombosis and Vascular Biology. 19:1034-1040.

6. Radino R, Poli E, Pela $G$ and Manca C(1989): Action of steroid sex hormones on the isolated rabbit heart. $\mathrm{J}$ Pharmacol.38:185-190.
7. Jiang C, Sarrel P, Lindsay D, Poole- Wilson $P$ and Collins $P$ (1992): Progesterone induces endothelium relaxation of rabbit coronary artery in vitro. European J Pharmacol. 211:163-167.

8. Molinari C, Battaglia A, Grossini E, Mary G, stoker B, Surico $N$ and Vacca $G$ (2006): The vasodilator effect of sex hormones on coronary blood flow of anaesthetized female pigs. Exp Physiol. 86(1):20762108.

9. Murphy I and Khalil R (1999): Decreased $\mathrm{Ca}^{+2}$ ion during smooth muscle contraction by $17-$ $\beta$ oestradiol, progesterone and testosterone. J Pharmacol and Exp Therap.219:44-51.

10. Miller VM and Vanhoutte P((1991): Progesterone and modulation of endothelium dependent responses in canine coronary arteries. American J Physiol.261:R1022-1027.

11. Rupnow HL, Phernetton TM, Shaw CE, Modrick ML, Bird IM, Magness RR (2001): Endothelial vasodilator production by uterine and systemic arteries. VII. Estrogen and progesterone effects on ENOS. Am J Physiol.28:H1699H1705.

12. Kakucs R, Varbiro S, Szekacs B, Nadasy GL, Acs N, Monos E(1998): Direct relaxing effect of estradiol-17beta and progesterone on rat saphenous artery. Microvasc Res. 56:139-143.

13. Mather KJ, Norman EG, Prior JC, Elliot TG (2000): Preserved forearm endothelial responses with acute exposure to 
progesterone: A randomized cross-over trial of 17-beta estradiol, progesterone, and 17beta estradiol with progesterone in healthy menopausal women. $\mathrm{J}$ Clin Endocrinol Metab .85:46444649.

14. Lee AF, McFarlane LC, Struthers AD (2000): Ovarian hormones in man: Their effects on resting vascular tone, angiotensin converting enzyme activity and angiotensin IIinduced vasoconstriction. $\mathrm{Br} \mathrm{J}$ Clin Pharmacol. 50:73-76.

15. Mercuro G, Pitzalis L, Podda A, Zoncu S, Pilia I, Melis GB, Cherchi A (1999): Effects of acute administration of natural progesterone on peripheral vascular responsiveness in healthy postmenopausal women. Am J Cardiol. 84:214-218.

16. Molinari C, Grossini E, Mary DASG, Vacca G(2000): Effect of distension of the gallbladder on plasma renin activity in anesthetized pigs. Circulation. 101:2539-2545.

17. Linden RJ, Mary DASG(1983): The preparation and maintenance of anaesthetized animals for the study of cardiovascular function; in Linden RJ (ed): Techniques in Cardiovascular Physiology (Techniques in the Life Sciences series). Shannon, Elsevier. pp 122.

18. Samaan SA, Crawford MH (1995): Estrogen and cardiovascular function after menopause. J Am Coll Cardiol .26:1403-1410.

19. Warren MP, Shantha S(1999): Uses of progesterone in clinical practice. Int J Fertil Women Med .44:96-103.

20. Mancia G, Donald DE, Shepherd JT (2001): Inhibition of adrenergic outflow to peripheral blood vessels by vagal afferents from the cardiopulmonary region in the dog. Circ Res.33:713-721.

21. Masilami S, Heesch CM (1997):

Effects of pregnancy and progesterone metabolites on arterial baroreflex in conscious rats. Am J Physiol .272:R924R934.

22. Laipraset JD, Rogers RC, Heesch CM (1998): Neurosteroid modulation of arterial baroreflex-sensitive neurons in rat rostral ventrolateral medulla. Am J Physiol .274:R903-R911.

23. Gregory NG, Wotton SB(1981): Autonomic and non-autonomic control of cardiovascular function in stress-sensitive pigs. J Vet Pharmacol Ther .4:183-191.

24. Henderson AH (1991): Endothelium in control. Br Heart J 1991;65:116-125.

25. Jones AW, Rubin LJ, Magliola L (1999): Endothelin-1 sensitivity of porcine coronary arteries is reduced by exercise training and is gender dependent. J Appl Physiol .87:1172-1177. 


\title{
دراسة عن تأثير هرمون البروجستيرون على الدورة الدموية في الثريان

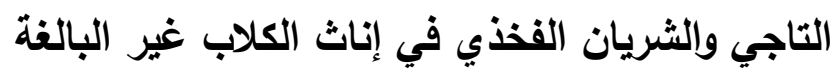

\author{
محمود عبد الحميد الغريب - روميساء على الثربينى

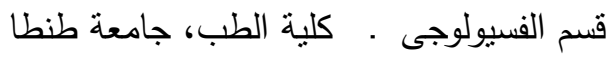

يهدف هذا البحث إلى دراسة تأثير حقن هرمون البروجستيرون على الدورة الدموية فى الئ

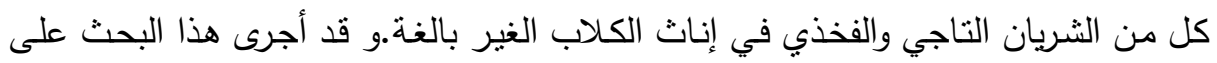

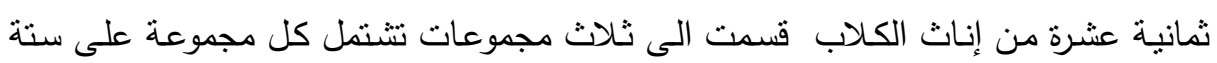

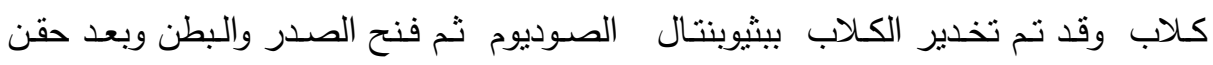

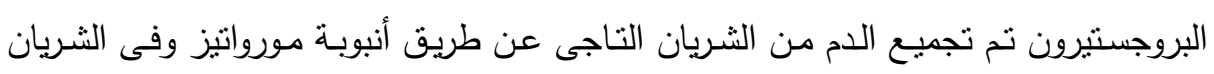

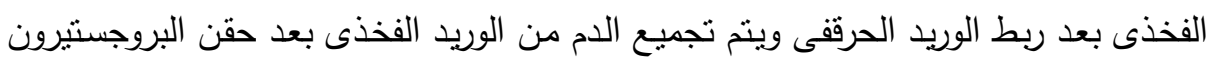

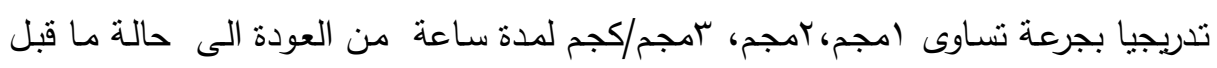

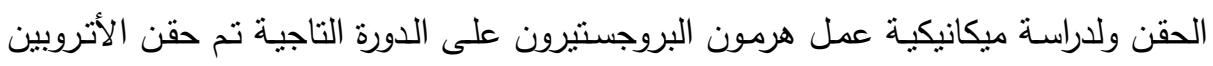

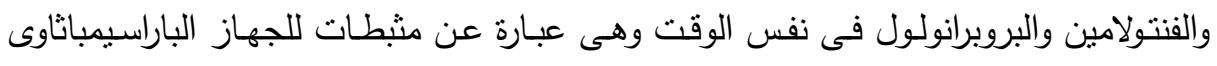

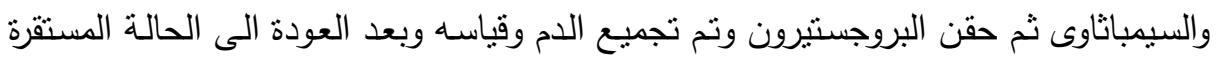

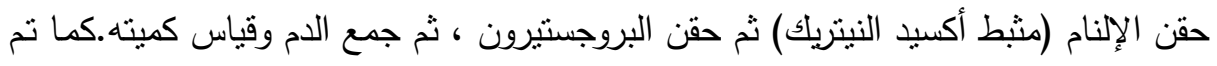

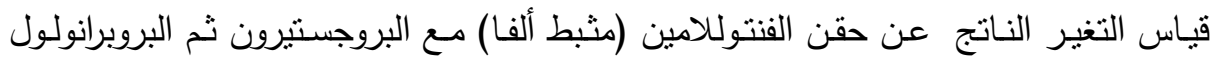

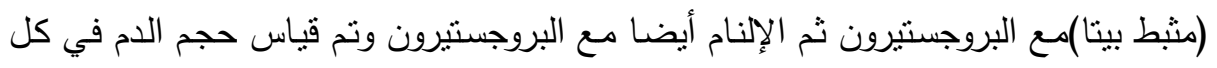

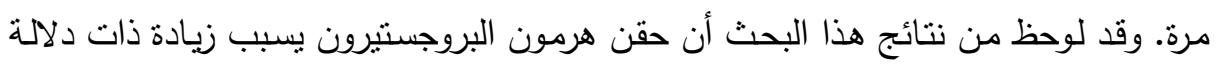

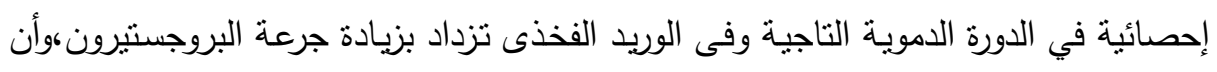

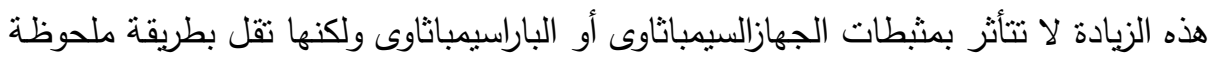

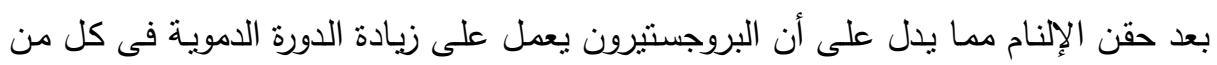
الثريان الثاجى و الفذذى. ويستخلص من هذا البحث أن هرمون البروجستيرون يعمل مباشرة على الأوعية الدموية. 